\title{
Vitamin D deficiency in elderly: Risk factors and drugs impact on vitamin D status
}

\author{
Hasan Kweder, Housam Eidi
}

Department of Geriatric Medicine, Hospital of Pierre Oudot, Bourgoin-Jallieu City, Isère Department, Region of Auvergne-Rhône-Alpes, France, ${ }^{1}$ Department of Ophthalmology and Visual Sciences, University of British Columbia, Vancouver, British Columbia, Canada

\begin{tabular}{|c|}
\hline Access this article online \\
\hline Website: www.avicennajmed.com \\
\hline DOI: 10.4103/ajm.AJM_20_18 \\
\hline Quick Response Code: \\
\hline
\end{tabular}

\begin{abstract}
Introduction: Vitamin D (VD) deficiency is a major public health problem worldwide. In spite of its high prevalence, particularly among elderly people, VD deficiency is still underestimated by many physicians. Increasingly, VD deficiency is associated with several known geriatric syndromes. Methods: The study sample consisted of 125 patients, aged 75 years and older, admitted to the acute geriatric unit. The plausible association between the serum 25 -hydroxyvitamin $D$ [25(OH)D] level and patient age, sex, body mass index, renal function, cholecystectomy history, and the prescribed drugs had been investigated. The Fisher's exact test was used to conduct the statistical analysis of data. Results: Surprisingly, furosemide treatment was correlated with normal $25(\mathrm{OH}) \mathrm{D}$ levels and an increased incidence of secondary hyperparathyroidism. Unlike the other four parameters mentioned above, our data showed that only the patient sex exhibited a significant association with $25(\mathrm{OH}) \mathrm{D}$ level as elderly males suffered from a serious VD deficiency as compared to elderly females. Conclusion: Old age is an independent risk factor for VD deficiency. The supplementary dose of VD should be precisely defined to achieve the optimal serum $25(\mathrm{OH}) \mathrm{D}$ level in elderly people. The definition of the normal serum $25(\mathrm{OH})$ $\mathrm{D}$ threshold in elderly furosemide-treated patients is worth of further studies.
\end{abstract}

Key words: Furosemide, geriatrics, Vitamin D deficiency

\section{INTRODUCTION}

Vitamin D (VD) or calciferol, a fat-soluble vitamin, ${ }^{[1]}$ is chemically classified as a steroid. ${ }^{[2]}$ There are two main sources of VD: the dietary and the endogenous synthesis. Vitamin D2 (ergocalciferol) is obtained from plants. While a small quantity of Vitamin D3 (cholecalciferol) is provided by animal-derived food, the main natural VD source is skin synthesis during sunlight exposure (exposure to ultraviolet $\mathrm{B}) .^{[3-5]}$ Regardless of its source, VD is hydroxylated in the liver to 25-hydroxyvitamin $\mathrm{D}[25(\mathrm{OH}) \mathrm{D}]$. 25(OH)D is then converted in the kidneys to its active form, namely 1,25-dihydroxyvitamin D [1,25(OH)2D]. Serum 25(OH) $\mathrm{D}$ level is often seen as a reflection of the total VD status. ${ }^{[6]}$

VD plays a crucial role in blood calcium and phosphate homeostasis supporting the body's metabolic functions,

Address for correspondence: Dr. Hasan Kweder,

Hospital of Pierre Oudot, Bourgoin-Jallieu, France.

E-mail: hasanisla@hotmail.com neuromuscular transmission, and bone mineralization. ${ }^{[7]}$ Furthermore, VD supplementation accelerates fracturehealing rates and decreases the risk of bone fracture. ${ }^{[8]}$ In regard to the elderly, a direct association between low $25(\mathrm{OH}) \mathrm{D}$ levels and frailty syndrome has recently been reported. ${ }^{[9]}$

It is worth mentioning, here, that $\mathrm{VD}$ also has noncalcemic and nonskeletal effects. Several studies have reported an inverse association between VD levels and the risk of oral, gastrointestinal, urinary, ocular, and respiratory infections. In addition, VD is widely known for its potent

This is an open access journal, and articles are distributed under the terms of the Creative Commons Attribution-NonCommercial-ShareAlike 4.0 License, which allows others to remix, tweak, and build upon the work non-commercially, as long as appropriate credit is given and the new creations are licensed under the identical terms.

For reprints contact: reprints@medknow.com

Cite this article as: Kweder $\mathrm{H}$, Eidi $\mathrm{H}$. Vitamin $\mathrm{D}$ deficiency in elderly: Risk factors and drugs impact on vitamin D status. Avicenna J Med 2018;8:139-46. 
immunomodulatory role since a strong relationship between VD deficiency and the prevalence of autoimmune disorders was observed. ${ }^{[10]}$ Other experimental and clinical studies have underscored the association between VD status and some neurological functions in human and animal models. Indeed, it has been reported that obese rats treated with VD supplementation showed a reduced inflammatory biomarkers in the hippocampus. ${ }^{[11]}$ Moreover, VD supplementation has also shown a significant improvement in the cognitive performance in elderly patients with senile dementia. ${ }^{[12]}$ VD deficiency affects the endocrinal function as it leads to increasing insulin resistance and an alteration in pancreatic $\beta$-cell function. ${ }^{[13]}$ Furthermore, VD supplementation decreases the fasting blood glucose in type 2 diabetic patients. ${ }^{[14]}$ Several clinical and epidemiological studies have highlighted the association between VD deficiency and various cardiovascular disorders, such as coronary artery disease, high blood pressure, congestive heart failure, peripheral arterial occlusive disease, stroke, and subarachnoid hemorrhage. ${ }^{[15-22]}$ Furthermore, many studies underscored the association between the low serum VD levels and many other diseases such as diabetic retinopathy, migraine, bladder carcinoma, and colorectal cancer. ${ }^{[23-26]}$

Although these documented associations between VD deficiency and prevalence of many disorders prevalence have been noted, the available studies conducted on the VD supplementation therapeutic effects have resulted in paradoxical data raising the need for further preclinical, epidemiological, and clinical studies to puzzle out the complex therapeutic benefits of VD. ${ }^{[10]}$

VD deficiency is a pandemic nutritional problem throughout the world. ${ }^{[27-31]}$ Interestingly, VD deficiency has been reported even in some equatorial countries, where people can get adequate sun exposure. ${ }^{[32-34]}$ It has been reported that more than one-third of human adults have low 25(OH)D levels. ${ }^{[35]}$ In addition, VD deficiency is often severe and significantly more seen in elderly people. ${ }^{[36]}$

The present study aims to evaluate the potential relationship between VD deficiency and six given risk factors: age, sex, body mass index (BMI), renal function, history of cholecystectomy, and the most frequent drugs taken by the elderly.

\section{METHODS}

\section{Study design}

Data of all patients admitted to the acute geriatric unit between November 2015 and April 2016 were analyzed. There were 125 patients, 52 men and 73 women. Patients were divided into two subgroups according to their age: old-old ( $\geq 75-84$ years) and oldest-old patients ( $>84$ years) [Figure 1]. ${ }^{[37]}$ These patients were interviewed and asked about their current intake of VD supplements as well as any previous prescription of VD taken during the preceding 3 years. Since VD supplementation could affect the serum $25(\mathrm{OH}) \mathrm{D}$ level for 3 years, ${ }^{[38]}$ an inability to obtain a detailed medication history for the preceding 3 years was the sole exclusion criteria.

We studied the association between serum 25(OH)D level and six parameters: age, sex, BMI, renal function, cholecystectomy history, and the influence of the prescribed drugs, such as furosemide, hydrochlorothiazide, fluindione, Coumadin, aspirin, clopidogrel, nebivolol, bisoprolol, irbesartan, amlodipine, atorvastatin, oxazepam, lorazepam, zopiclone, zolpidem, esomeprazole, tramadol, and modopar. To obtain the most accurate results possible, we excluded patients having VD supplementation when we studied the association between $25(\mathrm{OH}) \mathrm{D}$ status and these parameters.

\section{Laboratory assessments}

On the same day, serum concentrations of calcium, albumin, intact parathyroid hormone $(\mathrm{PTH})$, creatinine, and $25(\mathrm{OH}) \mathrm{D}$ were measured.

25(OH)D levels were categorized as follows: (1) very severe VD deficiency: $<12.5 \mathrm{nmol} / \mathrm{L}$; (2) severe VD deficiency: 12.5-24 nmol/L; (3) moderate VD deficiency: $25-49 \mathrm{nmol} / \mathrm{L}$; (4) minor VD deficiency: 50-74 nmol/L; and (5) normal VD level: $75-175 \mathrm{nmol} / \mathrm{L} .^{[39-41]}$

Glomerular filtration rate (GFR) was estimated by the CKDEPI (Chronic Kidney Disease - Epidemiology Collaboration) equation in $\mathrm{ml} / \mathrm{min} / 1.73 \mathrm{~m}^{2}$. GFR levels were classified as the following: (1) normal GFR: $\geq 90$; (2) slightly decreased GFR: 60-89; (3) chronic renal failure (CRF) at stage 3A: GFR between 45 and 59; (4) CRF at stage 3B: GFR between 30 and 44; (5) CRF at stage 4: GFR between 15 and 29; and (6) CRF stage 5: GFR $<15 \mathrm{ml} / \mathrm{min} / 1.73 \mathrm{~m}^{2}$. ${ }^{[42,43]}$

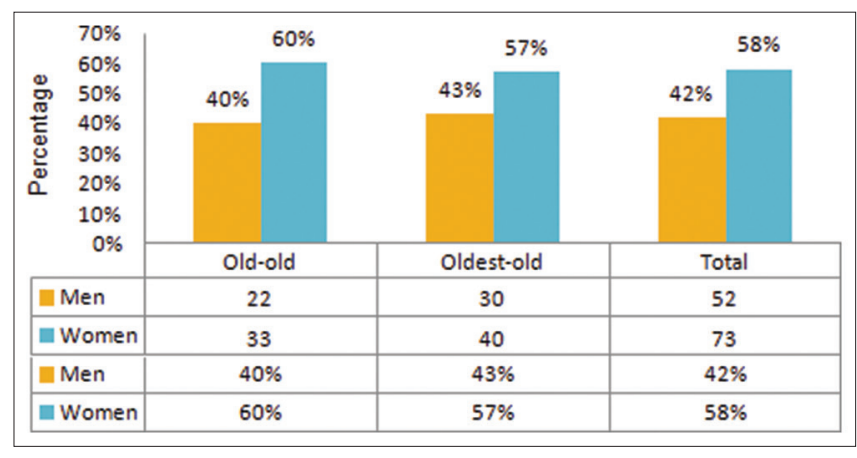

Figure 1: Age and sex distribution of the study sample of elderly patients. Patients were divided into two subgroups based on their age: old-old and oldest-old 
The BMI was calculated as weight $/$ height ${ }^{2} \mathrm{in} \mathrm{kg} / \mathrm{m}^{2}$. Patient nutrition status was classified as follows: (1) very severe malnutrition: BMI <18; (2) malnutrition: BMI between 18 and 20.99; (3) normal body weight: BMI between 21 and 24.99; (4) preobesity: BMI between 25 and 29.99; (5) class I obesity: BMI between 30 and 34.99; (6) class II obesity: BMI between 35 and 39.99; and (7) class III obesity: BMI $\geq 40 .^{[44,45]}$

\section{Statistical analysis}

Data were analyzed using the Fisher's exact test. $P<0.05$ was considered statistically significant.

\section{RESULTS}

\section{A high frequency of Vitamin D deficiency in the elderly}

Most patients had 25(OH)D levels that were less than those currently recommended for optimal health. Furthermore, very severe and severe forms accounted for up to $43 \%$ [Figure 2].

\section{Few elderly people receive Vitamin D supplementation}

Our data showed that no VD supplement treatment was given to more than $75 \%$ of patients during the preceding 3 years [Figure 3a]. Patients' age and gender had no association with this gap of VD prescription [Figure 3b].

\section{Elderly men are more likely to suffer from very severe Vitamin D deficiency}

Our data analysis showed that the prevalence of very severe VD deficiency in elderly men and elderly women was $44 \%$ and $26 \%$, respectively. This difference was statistically significant [Figure 4].

\section{There is no relationship between Vitamin D deficiency and age among the elderly}

Our results showed that no significant difference in serum 25(OH)D level was observed between "old-old" and "oldestold" subgroups [Figure 5], indicating that the age cannot be considered as a risk factor of VD deficiency in elderly people.

\section{Vitamin D deficiency affects elderly people with normal renal function}

GFR was evaluated in patients with very severe VD deficiency. We found that those patients had normal or mildly impaired renal function [Figure 6], indicating that elderly people can suffer from VD deficiency regardless of renal function status.

\section{Obesity in elderly people does not worsen Vitamin D deficiency}

Our data showed that no relationship was observed between the calculated BMI and the serum 25(OH)D level [Figure 7].

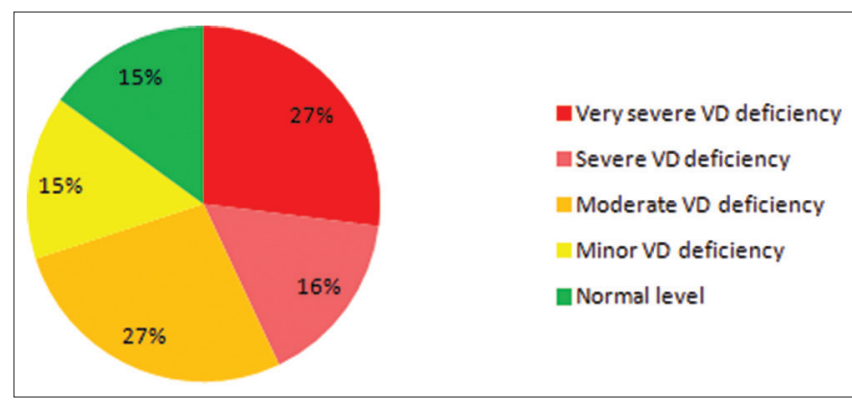

Figure 2: Vitamin D status in the study patient sample. More than a quarter of the patients were classified as "very sever Vitamin D deficiency" group. The Vitamin D recommended level was found only in $15 \%$ of the patients. No toxic levels were detected

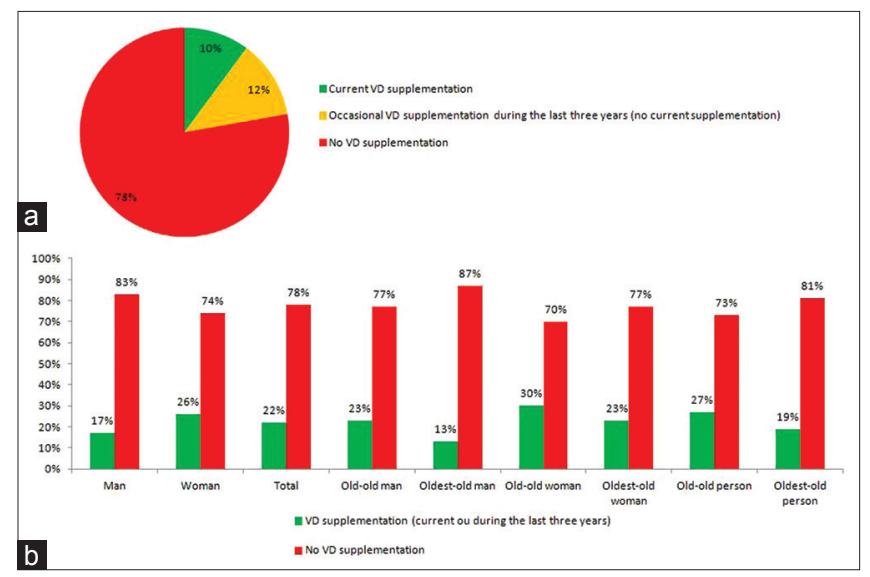

Figure 3: The rate of Vitamin D prescription. (a) The large majority of patients did not receive any Vitamin D supplementary treatment. (b) Vitamin D prescription in the different patient's subgroups

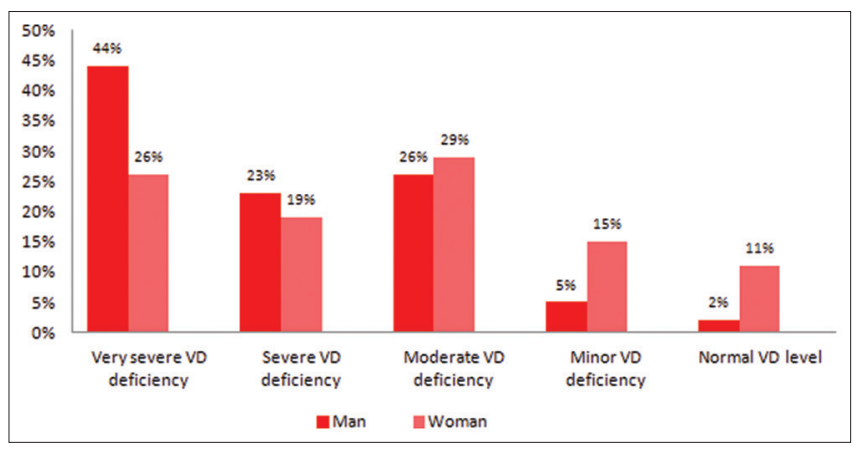

Figure 4: The sex effect on Vitamin D deficiency in elderly people. Elderly men are more affected by Vitamin D deficiency than women $(P$ Fisher $=0.041$ : men vs. women in the "very severe Vitamin D deficiency" group)

$P$ Fisher $<0.05$ was 0.256 for the comparison between obese patients and those with a normal BMI.

\section{Cholecystectomy has no effect on 25-hydroxyvitamin D level in the elderly}

Our findings showed that cholecystectomy does not affect the VD deficiency prevalence in the elderly [Figure 8]. $P$ Fisher $=0.38$ for the comparison between patient with VD deficiency and those with normal 25(OH)D status. 
$P$ Fisher $=0.43$ for the comparison between patient with very severe VD deficiency and those with normal $25(\mathrm{OH})$ D status.

\section{Furosemide increases serum 25-hydroxyvitamin D levels}

Furosemide is a loop diuretic commonly used in elderly patients (38\% of our patients). Our data analysis showed that the furosemide therapy was significantly associated with normal serum 25(OH)D levels [Figure 9]. $P$ Fisher $=0.037$ for the comparison between patients with VD deficiency and those with normal $25(\mathrm{OH}) \mathrm{D}$ status. $P$ Fisher $=0.024$ for the comparison between patients with very severe VD deficiency and those with normal $25(\mathrm{OH}) \mathrm{D}$ status.

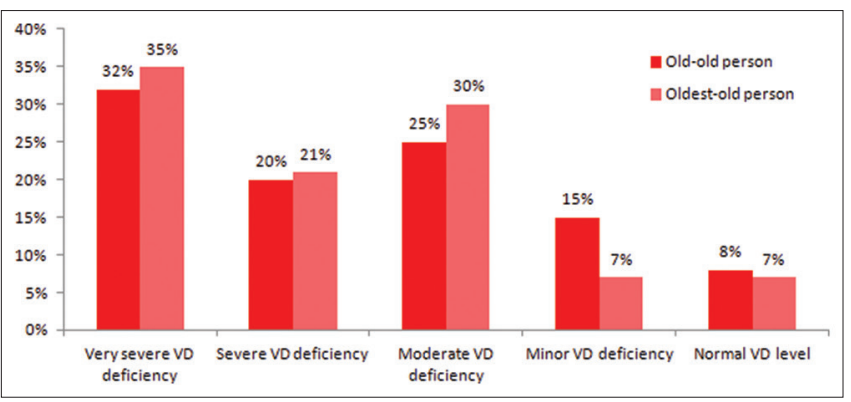

Figure 5: The age effect on Vitamin $D$ deficiency in elderly people. No significant effect of patient age was observed on their Vitamin D status ( $P$ Fisher $\geq 0.3$ )

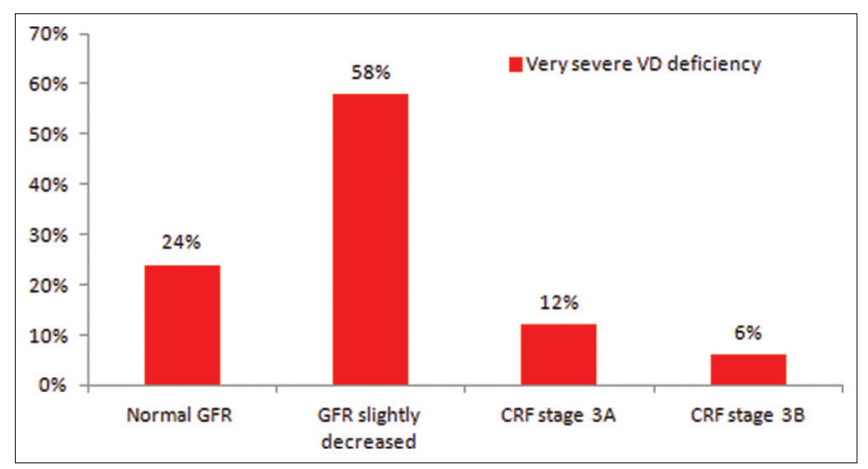

Figure 6: Renal function status in elderly people with very severe Vitamin D deficiency. $24 \%$ of patients had very severe Vitamin D deficiency despite of normal renal function
Furosemide increases the risk of secondary hyperparathyroidism

Our results showed that furosemide administration was associated with a greater chance of developing secondary hyperparathyroidism (sHPT). This association was statistically significant $(P$ Fisher $=0.0084)$ [Figure 10].

\section{DISCUSSION}

The prevalence of VD deficiency is still notably elevated. In the current study, only $15 \%$ of elderly people showed normal serum 25(OH)D level. Recent studies from France have also shown a small percentage of elderly people with normal VD status $(6 \%-7.5 \%) .^{[46,47]}$

A large-scale study has investigated the VD deficiency prevalence in adults aged $18-74$ years in France. ${ }^{[39]}$ This study demonstrated that very severe, severe, and moderate VD deficiencies were reported in $0 \%, 4.4 \%$, and $36.7 \%$ of individuals, respectively. Furthermore, more than 50\% of individuals had a serum $25(\mathrm{OH}) \mathrm{D}$ level $>50 \mathrm{nmol} / \mathrm{L}$. Nevertheless, the prevalence in the present study was $27 \%, 16 \%, 27 \%$, and $30 \%$ for very severe, severe, moderate VD deficiency, and for those with serum $25(\mathrm{OH}) \mathrm{D}$ levels $>50 \mathrm{nmol} / \mathrm{L}$, respectively.

These outcomes demonstrate that VD deficiency is a public health problem, predominately in the elderly. Lack of physical activities and sun exposure are most likely the key reasons behind this relevant VD deficiency in elderly people. ${ }^{[48]}$ In addition, VD synthesis in the skin is reported to be widely diminished in the elderly. ${ }^{[49]}$

An adequate VD and calcium intake should be achieved at any age, especially in childhood and in the elderly. ${ }^{[50]}$ Our data analysis showed that $78 \%$ of elderly people had not received any VD supplementation during the last 3 years. Furthermore, 90\% of elderly patients are not taking any current VD supplements. A daily VD intake of $400 \mathrm{IU}$ is recommended in France for individuals aged 65 years and

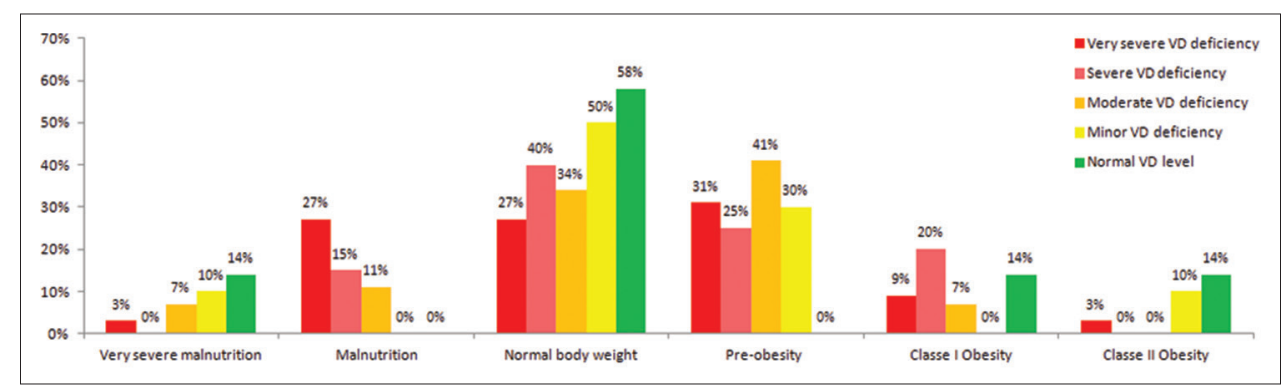

Figure 7: The effect of body mass index in elderly people on their Vitamin $D$ deficiency. No significant difference in Vitamin $D$ status was found $(P$ Fisher $\geq 0.1)$ 


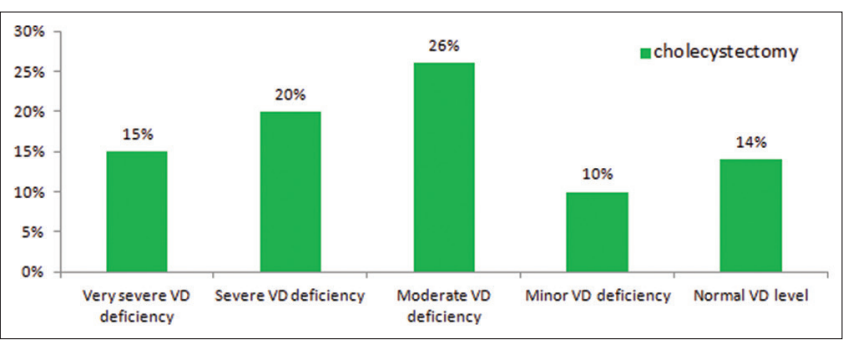

Figure 8: The association between Vitamin D status in elderly people and cholecystectomy history. Cholecystectomy has no significant effect on Vitamin $\mathrm{D}$ deficiency

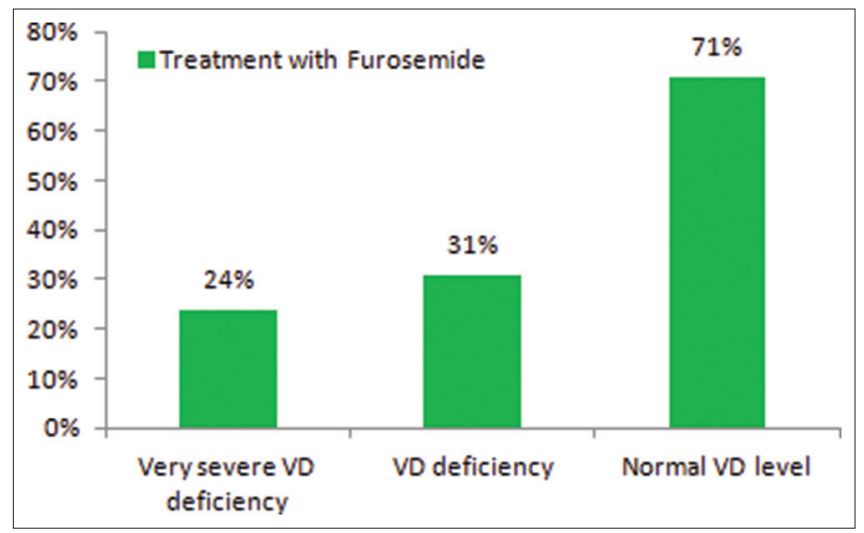

Figure 9: Furosemide treatment affects the Vitamin D status in elderly patients. Normal serum Vitamin D levels are more likely associated with the furosemide administration

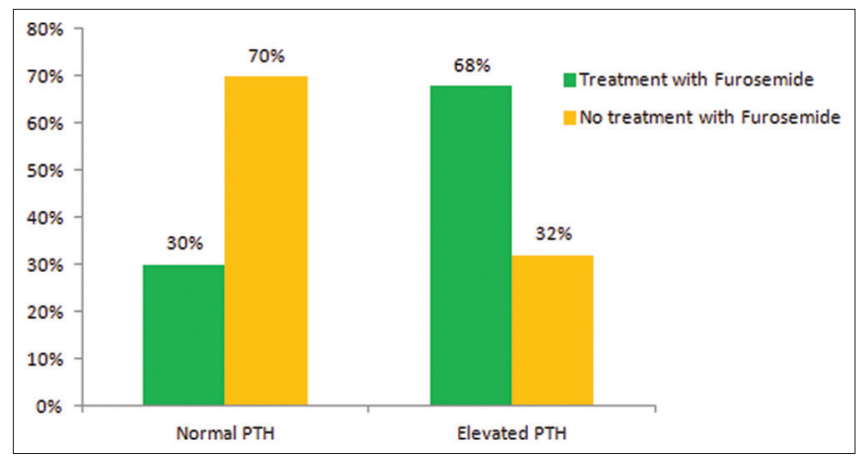

Figure 10: The relationship between furosemide treatment and parathyroid hormone status. A significant association between the increased level of parathyroid hormone and the furosemide treatment was observed $(P$ Fisher $=0.0084)$

over. ${ }^{[51]}$ However, many recent studies have recommended a daily dietary intake of VD ranging from 800 to $1000 \mathrm{IU} .{ }^{[52-54]}$ Unfortunately, these recommendations are poorly followed in clinical practice, even in high-risk individuals for VD deficiency. ${ }^{[55]}$ The daily average of VD intake in the elderly ranges from 100 to $200 \mathrm{IU}$ in the developed countries, such as the UK, Ireland, Denmark, the Netherlands, France, Germany, Hong Kong, Japan, and Canada. ${ }^{[36]}$

Our results showed that the very severe VD deficiency is seen more frequently in elderly men. This result seems to be inconsistent with the findings of some previous studies. ${ }^{[56-60]}$ These studies have reported that the low 25(OH)D levels in the elderly were seen more commonly in women compared to men.

As recently reported by Cheng et al., ${ }^{[57]}$ our data demonstrated that although VD deficiency is common in elderly people, ${ }^{[61,62]}$ the difference between old-old and oldest-old individuals is insignificant. Thus, all old people could be at a high risk of VD deficiency and they should receive VD supplement treatment regardless of their ages.

In the present study, no association between obesity and VD deficiency in the elderly was observed. This result seems to be consistent with a recent study from France. ${ }^{[60]}$ While Araghi et al. ${ }^{[63]}$ concluded that obesity in the elderly was associated with an increase in VD deficiency prevalence, Cheng et al. ${ }^{[57]}$ demonstrated that this relationship with obesity was seen only in elderly women.

The surgical history of cholecystectomy is frequently seen in elderly people. In the present study, $20 \%$ of the patients had undergone cholecystectomy. Given that bile salts are required for an efficient lipid and fat-soluble molecule absorption such as VD, cholecystectomy affects VD absorption. ${ }^{[64,65]}$ To the best our knowledge, to date, no data are available in the literature on the effect of cholecystectomy on $25(\mathrm{OH}) \mathrm{D}$ level in the elderly. Our analysis result did not show any association between cholecystectomy and $25(\mathrm{OH}) \mathrm{D}$ status. This outcome could be due to the recovery of postcholecystectomy syndrome within several weeks. ${ }^{[6]]}$

Renal function alterations are associated with an increasing VD deficiency rate. ${ }^{[67]}$ Indeed, it is due to the decreased renal 1 - $\alpha$-hydroxylase activity in addition to diminished hepatic 25-hydroxylase function related to uremia. ${ }^{[43,68,69]}$ Our study showed that elderly people can suffer from very severe VD deficiency, even with normal renal function status.

PTH plays a key role in calcium metabolism in the body as it stimulates bone reabsorption, increases serum calcium and phosphorus levels, and promotes synthesis of $1,25(\mathrm{OH}) 2 \mathrm{D} .{ }^{[70]}$ The main regulator for PTH secretion is the calcium-sensitive receptor (CaSR). ${ }^{[71]}$ Activation of CaSR by calcium inhibits rapidly PTH synthesis. In addition, the parathyroid glands express high levels of $\mathrm{VD}$ receptors, which, when activated by binding to 1,25(OH)2D, decreases PTH synthesis. In contrast, VD deficiency stimulates PTH synthesis. ${ }^{[72]}$ Furosemide is a loop diuretic that enhances urinary calcium excretion. ${ }^{[73]}$ Our study showed that furosemide treatment is associated with an increased prevalence rate of sHPT in the elderly. This effect is already observed in furosemide-treated patients 
in the general population. ${ }^{[74-77]}$ Hyperparathyroidism is associated with progressive vascular calcification and increases cardiovascular morbidity and mortality. ${ }^{[78-80]}$

sHPT is one of the methods used to determine the reference range for serum $25(\mathrm{OH}) \mathrm{D}$ concentration. Using this method, the lowest normal limit of serum $25(\mathrm{OH}) \mathrm{D}$ concentration is found to be $75 \mathrm{nmol} / \mathrm{L} .{ }^{[81]}$ Surprisingly, we demonstrated in the present study that furosemide administration is associated with normal serum $25(\mathrm{OH}) \mathrm{D}$ levels. Thus, the current normal threshold of serum 25(OH)D concentration for furosemide-treated patients must be reconsidered.

Some pharmacological therapies for systolic heart failure are associated with reduced morbidity and mortality, such as beta-blockers, angiotensin-converting enzyme inhibitors, angiotensin receptor blockers, and aldosterone antagonists. ${ }^{[82]}$ However, many recent studies highlighted the high mortality rates associated with furosemide use. ${ }^{[83-85]}$ It may be worthwhile, in the future studies, to investigate the plausible association between the furosemide-induced sHPT and the increased mortality. Therefore, our findings suggest that the increase of the minimal normal VD levels in serum up to an adequate proportional value associated with normal PTH concentration may lead to reduce the furosemide-related mortality.

\section{CONCLUSION}

VD has all the characters of a hormone. ${ }^{[86]}$ In the clinical practice, hypothyroidism, adrenal insufficiency, or other endocrine disorders get the full attention of physicians with good established treatment protocols; VD deficiency should be fully treated; and such a high rate of VD deficiency should not be accepted.

Like many other studies conducted in Europe, the present work showed that in such a rich region of the world, VD deficiency issues in the elderly cannot be adequately resolved by a simple change in food habits or even by food enrichment. Thus, pharmacological supplementation seems to be essential to prevent VD deficiency.

Our study indicates, for the first time, the great importance in determining the normal $25(\mathrm{OH}) \mathrm{D}$ threshold for furosemide-treated individuals.

\section{Financial support and sponsorship}

Nil.

\section{Conflicts of interest}

There are no conflicts of interest.

\section{REFERENCES}

1. Albahrani AA, Greaves RF. Fat-soluble vitamins: Clinical indications and current challenges for chromatographic measurement. Clin Biochem Rev 2016;37:27-47.

2. Harrison HE. Parathyroid hormone and Vitamin D. Yale J Biol Med 1966;38:393-409.

3. Avioli LV. Editorial: Vitamin D, the kidney and calcium homeostasis. Kidney Int 1972;2:241-6.

4. Shah D, Gupta P. Vitamin D deficiency: Is the pandemic for real? Indian J Community Med 2015;40:215-7.

5. Rosen CJ. Clinical practice. Vitamin D insufficiency. N Engl J Med 2011;364:248-54.

6. Holick MF. Vitamin D status: Measurement, interpretation, and clinical application. Ann Epidemiol 2009;19:73-8.

7. Molina P, Carrero JJ, Bover J, Chauveau P, Mazzaferro S, Torres PU, et al. Vitamin D, a modulator of musculoskeletal health in chronic kidney disease. J Cachexia Sarcopenia Muscle 2017;8:686-701.

8. Clutton J, Perera A. Vitamin D insufficiency and deficiency in patients with fractures of the fifth metatarsal. Foot (Edinb) 2016;27:50-2.

9. Gutiérrez-Robledo LM, Ávila-Funes JA, Amieva H, Meillon C, Acosta JL, Navarrete-Reyes AP, et al. Association of low serum 25-hydroxyvitamin D levels with the frailty syndrome in Mexican community-dwelling elderly. Aging Male 2016;19:58-63.

10. Prietl B, Treiber G, Pieber TR, Amrein K. Vitamin D and immune function. Nutrients 2013;5:2502-21.

11. Hajiluian G, Abbasalizad Farhangi M, Nameni G, Shahabi P, Megari-Abbasi M. Oxidative stress-induced cognitive impairment in obesity can be reversed by Vitamin D administration in rats. Nutr Neurosci 2017;2017:1-9.

12. Gangwar AK, Rawat A, Tiwari S, Tiwari SC, Narayan J, Tiwari S, et al. Role of Vitamin-D in the prevention and treatment of Alzheimer's disease. Indian J Physiol Pharmacol 2015;59:94-9.

13. Park S, Kim DS, Kang S. Vitamin D deficiency impairs glucose-stimulated insulin secretion and increases insulin resistance by reducing PPAR- $\gamma$ expression in nonobese type 2 diabetic rats. J Nutr Biochem 2016;27:257-65.

14. Calvo-Romero JM, Ramiro-Lozano JM. Metabolic effects of supplementation with Vitamin D in type 2 diabetic patients with Vitamin D deficiency. Diabetes Metab Syndr 2016;10:72-4.

15. Alvarado Y, Perez A, Rodriguez-Vega G. Effects of Vitamin D deficiency in aneurismal subarachnoid hemorrhage. Crit Care Med 2015;43 12 Suppl 1:138.

16. Chung PW, Park KY, Kim JM, Shin DW, Park MS, Chung YJ, et al. 25-hydroxy Vitamin D status is associated with chronic cerebral small vessel disease. Stroke 2015;46:248-51.

17. Mancuso P, Rahman A, Hershey SD, Dandu L, Nibbelink KA, Simpson RU, et al. 1,25-dihydroxyvitamin-D3 treatment reduces cardiac hypertrophy and left ventricular diameter in spontaneously hypertensive heart failure-prone $(\mathrm{cp} /+)$ rats independent of changes in serum leptin. J Cardiovasc Pharmacol 2008;51:559-64.

18. Nsengiyumva V, Fernando ME, Moxon JV, Krishna SM, Pinchbeck J, Omer SM, et al. The association of circulating 25-hydroxyvitamin D concentration with peripheral arterial disease: A meta-analysis of observational studies. Atherosclerosis 2015;243:645-51.

19. Pilz S, März W, Wellnitz B, Seelhorst U, Fahrleitner-Pammer A, Dimai HP, et al. Association of Vitamin D deficiency with heart failure and Sudden cardiac death in a large cross-sectional study of patients referred for coronary angiography. J Clin Endocrinol Metab 2008;93:3927-35.

20. Rahman A, Hershey S, Ahmed S, Nibbelink K, Simpson RU. Heart extracellular matrix gene expression profile in the Vitamin $\mathrm{D}$ receptor knockout mice. J Steroid Biochem Mol Biol 2007;103:416-9.

21. Tishkoff DX, Nibbelink KA, Holmberg KH, Dandu L, Simpson RU. Functional Vitamin D receptor (VDR) in the t-tubules of cardiac 
myocytes: VDR knockout cardiomyocyte contractility. Endocrinology 2008;149:558-64.

22. Weber KT, Simpson RU, Carbone LD. Vitamin D and calcium dyshomoeostasis-associated heart failure. Heart 2008;94:540-1.

23. Gungor A, Ates O, Bilen H, Kocer I. Retinal nerve fiber layer thickness in early-stage diabetic retinopathy with Vitamin D deficiency. Invest Ophthalmol Vis Sci 2015;56:6433-7.

24. Mottaghi T, Askari G, Khorvash F, Maracy MR. Effect of Vitamin D supplementation on symptoms and C-reactive protein in migraine patients. J Res Med Sci 2015;20:477-82.

25. Zhang H, Zhang H, Wen X, Zhang Y, Wei X, Liu T, et al. Vitamin D deficiency and increased risk of bladder carcinoma: A meta-analysis. Cell Physiol Biochem 2015;37:1686-92.

26. Marques Vidigal V, Aguiar Junior PN, Donizetti Silva T, de Oliveira J, Marques Pimenta CA, Vitor Felipe A, et al. Genetic polymorphisms of Vitamin D metabolism genes and serum level of Vitamin D in colorectal cancer. Int J Biol Markers 2017;32:e441-6.

27. Burnand B, Sloutskis D, Gianoli F, Cornuz J, Rickenbach M, Paccaud F, et al. Serum 25-hydroxyvitamin D: Distribution and determinants in the Swiss population. Am J Clin Nutr 1992;56:537-42.

28. Flicker L, Mead K, MacInnis RJ, Nowson C, Scherer S, Stein MS, et al. Serum Vitamin D and falls in older women in residential care in Australia. J Am Geriatr Soc 2003;51:1533-8.

29. Ginde AA, Liu MC, Camargo CAJr. Demographic differences and trends of Vitamin D insufficiency in the US population, 1988-2004. Arch Intern Med 2009;169:626-32.

30. Genuis SJ, Schwalfenberg GK, Hiltz MN, Vaselenak SA. Vitamin D status of clinical practice populations at higher latitudes: Analysis and applications. Int J Environ Res Public Health 2009;6:151-73.

31. Oliveri B, Plantalech L, Bagur A, Wittich AC, Rovai G, Pusiol E, et al. High prevalence of Vitamin D insufficiency in healthy elderly people living at home in Argentina. Eur J Clin Nutr 2004;58:337-42.

32. Hashemipour S, Larijani B, Adibi H, Javadi E, Sedaghat M, Pajouhi M, et al. Vitamin D deficiency and causative factors in the population of Tehran. BMC Public Health 2004;4:38.

33. Riaz H, Finlayson AE, Bashir S, Hussain S, Mahmood S, Malik F, et al. Prevalence of Vitamin D deficiency in Pakistan and implications for the future. Expert Rev Clin Pharmacol 2016;9:329-38.

34. Trilok Kumar G, Chugh R, Eggersdorfer M. Poor Vitamin D status in healthy populations in India: A review of current evidence. Int J Vitam Nutr Res 2015;85:185-201.

35. Fanari Z, Hammami S, Hammami MB, Hammami S, Abdellatif A. Vitamin D deficiency plays an important role in cardiac disease and affects patient outcome: Still a myth or a fact that needs exploration? J Saudi Heart Assoc 2015;27:264-71.

36. Lips P. Vitamin D deficiency and secondary hyperparathyroidism in the elderly: Consequences for bone loss and fractures and therapeutic implications. Endocr Rev 2001;22:477-501.

37. Comploj E, West J, Mian M, Kluth LA, Karl A, Dechet C, et al. Comparison of complications from radical cystectomy between old-old versus oldest-old patients. Urol Int 2015;94:25-30.

38. Martinaityte I, Kamycheva E, Didriksen A, Jakobsen J, Jorde R. Vitamin $D$ stored in fat tissue during a 5-year intervention affects serum 25-hydroxyvitamin D levels the following year. J Clin Endocrinol Metab 2017; 102:3731-8.

39. ENNS: Étude Nationale Nutrition Santé. Translated title: National study of nutritional health. Nutritional situation in France in 2006 according to the objective indicators and les scales of the national program of nutritional health. Saint-Maurice: INVS; 2007.

40. Hanley DA, Cranney A, Jones G, Whiting SJ, Leslie WD, Cole DE, et al. Vitamin $D$ in adult health and disease: A review and guideline statement from osteoporosis Canada. CMAJ 2010;182:E610-8.

41. Benhamou CL, Souberbielle JC, Cortet B, Fardellone P, Gauvain JB, Thomas T. For the research and information group of osteoporosis.
The vitamin D in adults. Recommendations of the GRIO. Presse Med 2011;40:673-82.

42. Levey AS, Coresh J, Balk E, Kausz AT, Levin A, Steffes MW, et al. National kidney foundation practice guidelines for chronic kidney disease: Evaluation, classification, and stratification. Ann Intern Med 2003; 139:137-47.

43. HAS. Chronic kidney disease in adults; 2012.

44. WHO Expert Consultation. Appropriate body-mass index for Asian populations and its implications for policy and intervention strategies. Lancet 2004;363:157-63.

45. HAS. Management strategy in case of protein-energy malnutrition in the elderly; 2007.

46. Annweiler C, Pochic S, Fantino B, Legrand E, Bataille R, Montero-Odasso M, et al. Serum Vitamin D concentration and short-term mortality among geriatric inpatients in acute care settings. Adv Ther 2010;27:245-9.

47. Crétel E, Veen I, Pierres A, Binan Y, Robert P, Loundou AD, et al. Immune profile of elderly patients admitted in a geriatric short care unit. Rev Med Interne 2011;32:275-82.

48. Wyskida M, Wieczorowska-Tobis K, Chudek J. Prevalence and factors promoting the occurrence of Vitamin D deficiency in the elderly. Postepy Hig Med Dosw (Online) 2017;71:198-204.

49. Holick MF, Matsuoka LY, Wortsman J. Age, Vitamin D, and solar ultraviolet. Lancet 1989;2:1104-5.

50. Briot K, Cortet B, Thomas T, Audrand M, Blaine H, Breuilf V, et al. Update 2012 of the French recommendations for the medicinal treatment of postmenopausal osteoporosis. Rev Rhum 2012;79:264-74.

51. Martin A. Recommended nutritional intake for the French population. $3^{\text {rd }}$ ed. Paris: Tec and Doc, Lavoisier; 2001.

52. Bischoff-Ferrari H. Vitamin D: What is an adequate Vitamin D level and how much supplementation is necessary? Best Pract Res Clin Rheumatol 2009;23:789-95.

53. Ross AC, Manson JE, Abrams SA, Aloia JF, Brannon PM, Clinton SK, et al. The 2011 report on dietary reference intakes for calcium and Vitamin D from the institute of medicine: What clinicians need to know? J Clin Endocrinol Metab 2011;96:53-8.

54. Souberbielle JC, Body JJ, Lappe JM, Plebani M, Shoenfeld Y, Wang TJ, et al. Vitamin D and musculoskeletal health, cardiovascular disease, autoimmunity and cancer: Recommendations for clinical practice. Autoimmun Rev 2010;9:709-15.

55. Cianferotti L, Parri S, Gronchi G, Civinini R, Brandi ML. The use of cholecalciferol in patients with hip fracture. Clin Cases Miner Bone Metab 2017;14:48-53.

56. Carrillo-Vega MF, García-Peña C, Gutiérrez-Robledo LM, Pérez-Zepeda MU. Vitamin D deficiency in older adults and its associated factors: A cross-sectional analysis of the Mexican health and aging study. Arch Osteoporos 2017;12:8.

57. Cheng Q, Du Y, Hong W, Tang W, Li H, Chen M, et al. Factors associated to serum 25-hydroxyvitamin D levels among older adult populations in urban and suburban communities in Shanghai, China. BMC Geriatr 2017; 17:246.

58. Huang CH, Huang YA, Lai YC, Sun CK. Prevalence and predictors of hypovitaminosis D among the elderly in subtropical region. PLoS One 2017;12:e0181063.

59. Lopes JB, Fernandes GH, Takayama L, Figueiredo CP, Pereira RM. A predictive model of Vitamin D insufficiency in older community people: From the São Paulo aging \& health study (SPAH). Maturitas 2014;78:335-40.

60. Annweiler C, Riou J, Alessandri A, Gicquel D, Henni S, Féart C, et al. Clinical identification of geriatric patients with hypovitaminosis D: The 'Vitamin D status predictor for geriatrics' study. Nutrients 2017;9: pii: E658.

61. Mithal A, Wahl DA, Bonjour JP, Burckhardt P, Dawson-Hughes B, Eisman JA, et al. Global Vitamin D status and determinants of hypovitaminosis D. Osteoporos Int 2009;20:1807-20. 
62. Pinkas J, Bojar I, Gujski M, Bartosińska J, Owoc A, Raczkiewicz D, et al. Serum lipid, Vitamin D levels, and obesity in perimenopausal and postmenopausal women in non-manual employment. Med Sci Monit 2017;23:5018-26.

63. Araghi SO, van Dijk SC, Ham AC, Brouwer-Brolsma EM, Enneman AW, Sohl E, et al. BMI and body fat mass is inversely associated with Vitamin D levels in older individuals. J Nutr Health Aging 2015;19:980-5.

64. Koricheva ES, Il'chenko AA, Selezneva Ela, Drozdov VN. Disorders of bone mineral density in patients with cholelithiasis and postcholecystectomic syndrome. Eksp Klin Gastroenterol 2010;4:14-20.

65. Marcinowska-Suchowierska EB, Tałałaj MJ, Włodarcyzk AW, Bielecki K, Zawadzki JJ, Brzozowski R, et al. Calcium/phosphate/Vitamin D homeostasis and bone mass in patients after gastrectomy, vagotomy, and cholecystectomy. World J Surg 1995;19:597-601.

66. Stoker GE, Buchowski JM, Stoker ME. Prior cholecystectomy as a predictor of preoperative Vitamin D deficiency in adults undergoing spine surgery. Arch Surg 2012;147:577-8.

67. Chonchol M, Scragg R. 25-hydroxyvitamin D, insulin resistance, and kidney function in the Third National Health and Nutrition Examination Survey. Kidney Int 2007;71:134-9.

68. Ernandez T, Stoermann-Chopard C. Vitamin D and chronic kidney disease: Increasing role for an old vitamin. Rev Med Suisse 2012;8:2140-5.

69. Michaud J, Naud J, Ouimet D, Demers C, Petit JL, Leblond FA, et al. Reduced hepatic synthesis of calcidiol in uremia. J Am Soc Nephrol 2010;21:1488-97.

70. Saliba W, El-Haddad B. Secondary hyperparathyroidism: Pathophysiology and treatment. J Am Board Fam Med 2009;22:574-81.

71. McCann LM, Beto J. Roles of calcium-sensing receptor and Vitamin D receptor in the pathophysiology of secondary hyperparathyroidism. J Ren Nutr 2010;20:141-50.

72. Gallieni M, Cozzolino M, Fallabrino G, Pasho S, Olivi L, Brancaccio D, et al. Vitamin D: Physiology and pathophysiology. Int J Artif Organs 2009;32:87-94.

73. Constant J. Pearls and pitfalls in the use and abuse of diuretics for chronic congestive heart failure. Cardiology 1999;92:156-61.

74. Stein MS, Scherer SC, Walton SL, Gilbert RE, Ebeling PR, Flicker L, et al.
Risk factors for secondary hyperparathyroidism in a nursing home population. Clin Endocrinol (Oxf) 1996;44:375-83.

75. Karlsson SL, Indridason OS, Franzson L, Sigurdsson G. Prevalence of secondary hyperparathyroidism (SHPT) and causal factors in adult population in Reykjavík area. Laeknabladid 2005;91:161-9.

76. Arampatzis S, Gaetcke LM, Funk GC, Schwarz C, Mohaupt M, Zimmermann $\mathrm{H}$, et al. Diuretic-induced hyponatremia and osteoporotic fractures in patients admitted to the emergency department. Maturitas 2013;75:81-6.

77. Drinka PJ, Krause PF, Nest LJ, Goodman BM. Determinants of parathyroid hormone levels in nursing home residents. J Am Med Dir Assoc 2007;8:328-31.

78. Aktas Yılmaz B, Akyel A, Kan E, Ercin U, Tavil Y, Bilgihan A, et al. Cardiac structure and functions in patients with asymptomatic primary hyperparathyroidism. J Endocrinol Invest 2013;36:848-52.

79. Ozdemir D, Kalkan GY, Bayram NA, Onal ED, Ersoy R, Bozkurt E, et al. Evaluation of left ventricle functions by tissue Doppler, strain, and strain rate echocardiography in patients with primary hyperparathyroidism. Endocrine 2014;47:609-17.

80. Torres PA, De Broe M. Calcium-sensing receptor, calcimimetics, and cardiovascular calcifications in chronic kidney disease. Kidney Int 2012;82:19-25.

81. HAS. Clinical utility of the vitamin D assay; 2013.

82. Nair AP, Timoh T, Fuster V. Contemporary medical management of systolic heart failure. Circ J 2012;76:268-77.

83. Kapelios CJ, Kaldara E, Ntalianis A, Sousonis V, Repasos E, Sfakianaki T, et al. High furosemide dose has detrimental effects on survival of patients with stable heart failure. Hellenic J Cardiol 2015;56:154-9.

84. Rokutan H, Suckow C, von Haehling S, Strassburg S, Bockmeyer B, Doehner $\mathrm{W}$, et al. Furosemide induces mortality in a rat model of chronic heart failure. Int J Cardiol 2012;160:20-5.

85. Singh A, Blackwell J, Neher J. Clinical inquiries. Does furosemide decrease morbidity or mortality for patients with diastolic or systolic dysfunction? J Fam Pract 2005;54:370-2.

86. Annweiler C, Souberbielle JC, Schott AM, de Decker L, Berrut G, Beauchet $\mathrm{O}$, et al. Vitamin D in the elderly: 5 points to remember. Geriatr Psychol Neuropsychiatr Vieil 2011;9:259-67. 